\title{
TEACHING ENTREPRENEURSHIP REDIRECT FOR YOUNG PEOPLE IN MODERN CONDITIONS
}

\author{
Makhliyokhon Madaminjonovna Mirzakarimova \\ Researcher of Andizhan State University, Andizhan region, Republic of Uzbekistan
}

Article DOI: https://doi.org/10.36713/epra4858

\begin{abstract}
This article analyzes the importance of the system of entrepreneurship-oriented education in the training of entrepreneurs. In addition, the study provides insights into the educational process aimed at training entrepreneurs at various stages of human activity, not only in public educational institutions, but also in the formation of a market economy, business development and the ability to realize their potential as well.
\end{abstract}

KEY WORDS: Development of entrepreneurship, business education, management, business process, production, human activity, economics, public education.

\section{INTRODUCTION}

According to global trends, the preparation of young people for entrepreneurship will create jobs in the education system of advanced countries and reduce unemployment, increase the volume of goods and services, the introduction of social programs and solve other socio-economic problems [1, p.37-42]. An important task of economic reforms in our country is to increase the economic efficiency of production, and the main way to solve it is to increase the interest of workers in the results of labor [2].

\section{METHODS}

There are some methods in the field of entrepreneurship-oriented education in the training of entrepreneurs. Also, market relations have led to an increase in the demand for employees who have the ability to do business in the labor market, to solve various problems in their workplace.

\section{RESULTS AND DISCUSSIONS}

Radical changes in social, production and management relations, the emergence and development of economic structures based on different forms of ownership require the establishment of a system of additional educational institutions in the form of business education, meeting the needs of the economy and population, professional compactness.

The system of entrepreneurship-oriented general education is one of the most important forms of training of entrepreneurs. is calculated.

One of the main conditions for the development and expansion of small business and private entrepreneurship is the training of qualified entrepreneurs. The deepening of market relations, the expansion of production of goods and services that meet the needs of consumers, the growth of employment depends on the knowledge and skills of the leaders of private enterprises. The modern economy is formed by intelligent entrepreneurs who know their job well.

The need for a system of entrepreneurshiporiented teaching of general education has arisen in connection with the introduction of market relations, denationalization, privatization and the emergence of various forms of ownership [3]. Private property has led to the formation of a class of entrepreneurs who require knowledge in addition to the general education and vocational knowledge previously acquired.

To implement this idea, it is necessary to train the population in business. Entrepreneurship-oriented teaching of general subjects and vocational training of students is the main system that ensures the 


\section{SJIF Impact Factor: 7.001| ISI I.F.Value:1.241| Journal DOI: 10.36713/epra2016

maintenance and increase of human capital in the country. The speed and efficiency of knowledge transfer by education systems determine the rate of development of human capital. The formation of human capital affects the growth rates of the property class.

The unified system of education, training for the non-governmental sector of the economy, should begin in secondary and vocational schools and end in secondary special vocational and higher education institutions, as well as in the system of postgraduate vocational education (postgraduate education).

Establishment of such a system requires concerted action of government agencies, social organizations, the media at various (territorial, municipal) levels. These actions are based on the adoption of state legislation, the allocation of special funds, the interaction of all interested organizations. A positive result can be achieved through the combined efforts of all levels of education, from secondary special to higher and alternative business education system. Many agree, but the ability of the state and society to use this support to the end is one of the most pressing issues.

In order to better understand the role and place of the system of entrepreneurship-oriented education, we need to define its main function, the content of the education system, because today the training, education and training of qualified personnel for all sectors of the economy is mainly the responsibility of entrepreneurship-oriented education. In addition, the continuous improvement of the general education and special professional level of those engaged in public production is becoming a necessity of society and the market economy. Therefore, the content of the education system, including the system of entrepreneurship-oriented teaching of general education subjects, is in a continuous stage of development [4].

Despite the large allocation of resources by the state, the new tasks of business education and training for the business sector require further expansion of funding sources. The share of education costs in the cost of a competitive product in world markets is at least $10 \%[5, \mathrm{p} .170]$. Most businesses in the country allocate very little to improve the skills of their employees, within $2-3 \%$ of the total cost of enterprises, due to high production costs, a number of tax burdens that reduce the interest of businesses to expand production and innovation.

For the private sector of the economy, the improvement of the system of entrepreneurshiporiented teaching of educational institutions necessitated the transition to life itself, the transition to market relations, especially to increase employment in rural areas [6, p.62-64]. The acquired knowledge is used in business.

The requirements of the state concept in the system of entrepreneurship-oriented teaching of public and private structures should be based on the following principles [7]:

- universal values and the priority of free development of the individual: fostering patriotism, diligence, respect for human rights and freedoms;

- Equality of education for all, flexibility of the education system to the level and characteristics of the development of entrepreneurship training:

- freedom and pluralism of business education;

- continuity and consistency of the education system;

- Integration of general, secondary special, higher education and postgraduate education, while preserving the achievements of science and technology and national traditions in the global business and entrepreneurship-oriented education system [8];

- Transparency in determining the direction of development of science and technology, as well as training, retraining and advanced training of employees of business structures.

In the concept of an entrepreneurship-oriented education system, ensuring the continuity of education should be shaped by historical and national traditions. Normative legal acts should ensure the delimitation of powers in the field of education between public authorities and education authorities at different levels, as well as public and non-public education systems. The constitutional rights of citizens to receive any type of education, including postgraduate education, must be protected. It is also necessary to create legal guarantees for the free operation of entrepreneurship-oriented training and business education in the territory of Uzbekistan, defining the rights, obligations, powers and responsibilities of individuals and legal entities in this form of training, as well as the legal regulation of their relations.

In-depth knowledge in the field of marketing, management, finance, accounting from a growing business sole proprietor; to know how to compromise; requires the ability to negotiate and work in a team. It is necessary to cover a set of general education disciplines in the training of specialists for business and entrepreneurship.

Nowadays, the main requirements for training young entrepreneurs are knowledge, management skills and personal entrepreneurial characteristics (Table 1). 


\section{EPRA International Journal of Research and Development (IJRD) Volume: 5 | Issue: 7 | July 2020 \\ - Peer Reviewed Journal}

Table 1. Requirements for training young entrepreneurs [9]

\begin{tabular}{|c|c|c|}
\hline Knowledge & Management skills & $\begin{array}{l}\text { Personal business } \\
\text { characteristics }\end{array}$ \\
\hline $\begin{array}{c}\text { business opportunity } \\
\text { opportunity to create business } \\
\text { plans } \\
\text { know how to serve customers } \\
\text { production processes } \\
\text { ability to negotiate } \\
\text { business management } \\
\text { market } \\
\text { competitors } \\
\text { legal basis of entrepreneurship } \\
\text { sources of assistance and funding }\end{array}$ & $\begin{array}{c}\text { marketing } \\
\text { financial management } \\
\text { production and organization of } \\
\text { labor } \\
\text { planning } \\
\text { leadership coaching: a modern } \\
\text { type of personnel management }\end{array}$ & $\begin{array}{c}\text { leadership } \\
\text { to act within the limits of } \\
\text { possibilities } \\
\text { search for information } \\
\text { individually } \\
\text { practice } \\
\text { ability to perform contracts } \\
\text { problem solving } \\
\text { regular planning } \\
\text { ability to take risks }\end{array}$ \\
\hline
\end{tabular}

The deepening of economic reforms, investment policy and active structural changes in the economy, the development of small business and private entrepreneurship, the expansion of the network of market structures and self-employment have led to the development of non-traditional forms of educational institutions.

It should be noted that in the system of entrepreneurship-oriented education, due to the lack of state standards and a clear mechanism for training teachers of general education, training can not quickly adapt to the changing needs of retraining for a market economy. Market relations demanded the transition from a unitary, state-style form of education to a system of selective education. This has become a key area of education reform in the country.

In this case, "Who to be?" The question is "Who needs it?" that is, the training of the labor force must be in accordance with the requirements and needs of the economy (Table 2).

Table 2. Demands and needs of the economy in the system of entrepreneurship-oriented education [10]

\begin{tabular}{|c|c|}
\hline Who to be? & Who needs it? \\
\hline $\begin{array}{c}\text { Orientation of students to the scientific and } \\
\text { organizational profession in accordance with } \\
\text { the needs of the economy }\end{array}$ & $\begin{array}{c}\text { Ensuring that knowledge is constantly in line with } \\
\text { the requirements of new techniques and } \\
\text { technologies }\end{array}$ \\
$\begin{array}{c}\text { Development and improvement of workforce } \\
\text { training processes, such as retraining and advanced } \\
\text { training of personnel }\end{array}$ \\
$\begin{array}{c}\text { Creation of a system of professional and } \\
\text { professional development of personnel } \\
\text { Selection of the most effective forms of training }\end{array}$ \\
\hline
\end{tabular}

\section{CONCLUSION}

In our opinion, in order to meet the needs of the Uzbek economy for entrepreneurial personnel in the context of deepening market reforms, it is necessary to develop a more effective program of entrepreneurship-oriented general education. The program should take into account the promising trends in the formation of entrepreneurial skills in students and the growth of the number of selfemployed youth, and provide for the expansion of the use of various forms of training of broad-based entrepreneurs. In addition, it is necessary to consider what new factors may affect the training of personnel in Uzbekistan.
The following factors affect the demand for specialists in a wide range of areas, both in the public and private sectors:

- development of labor;

- the need to meet ever-increasing needs;

- The need to increase labor productivity;

- Technological and industrial changes;

- The need for training and retraining of personnel directly in the firm;

- Introduction of new types of professions in world practice.

In this regard, business education will increase the following sides:

- Becomes a comprehensive education in the teaching of know-how; 
- Be responsible, which allows you to quickly adapt to changes;

- Motivated, which helps to develop in each student the desire to continue learning;

- Integrated, ie rationally combines theoretical and practical reading.

\section{REFERENCES}

1. Teaching Business Ethics: IN THE AGE OF MADOFF. Author(s): R. Edward Freeman, Lisa Stewart and Brian Moriarty. Source: Change,Vol. 41, No. 6 (November/December 2009), pp. 37-42. Published by: Taylor \& Francis, Ltd. Stable URL: http://www.jstor.org/stable/20696192. Accessed: 18-04-2018 11:24 UTC.

2. Bakieva I.A. The system of training entrepreneurs in Uzbekistan and the features of its reform Scientific electronic journal "Economy and Innovative Technologies", T., 2011, No.2.

3. Robson, Colin. 2002. Real World Research: A Resource for Social Scientists and PractitionerResearchers, Malden: Blackwell.

4. Polonsky V.M. Research methods of educational problems. -M: Pedagogy, 1994.

5. Formation a culture of independent thinking in the educational process: materials of the international scientific conference on November 10-11, 2015.- Prague : Vědecko vydavatelské centrum «Sociosféra-CZ», 2015. - 170 p. - ISBN 978-80-7526-061-1.

6. Sharipova M.H. Entrepreneurial activity is a characteristic feature of a leader in school management // Educational technologies, T., 2016, issue 6 - pp. 62-64.

7. http://www.jstor.org/stable/25072888.

8. University Microfilms. 300 North Zeeb Road. Ann Arbor, Michigan 48106. A Xerox Education Company. NEW YORK U N I V E R S I T Y. SCHOOL OF EDUCATION. HORARY.

9. Malikov T. Financial management - T: "Academy" - 1999.

10. http://www.jstor.org/stable/20696192. 